\title{
Recent Trends in Resistance Spot Welding of Aluminium Alloys in Automotive Industry
}

\author{
B.D.Y.Sunil \\ Assistant Professor, Department of Mechanical Engineering, \\ Institute of Aeronautical Engineering, Dundigal, Hyderabad - 500043, Telangana State, India \\ Dr. Banoth Balu Naik \\ Professor of Mechanical Engineering \& Director, \\ UGC-HRDC JNTUH, Kukatpally, Hyderabad-500085, India,
}

\begin{abstract}
As a response to ever increasing requirements for fuel efficient and environmental- friendly vehicles, the usage of aluminum products in automobiles is increasing day-to-day. Especially, Aluminium alloys are used as an alternative material for car-bodies in automotive industry. For the increasing demands in higher strength and better formability in light weight and crash worthiness aspects, special Aluminium alloys are developed. As a result, a variety of new technologies are being developed for working and fabrication of Aluminium products. This paper highlights the process of Resistance Spot Welding (RSW), properties of Aluminum and Aluminium alloys, preparation of Aluminium material for welding process, as well as the resistance spot welding of Aluminium alloys. The average and specific usage of Aluminium in passenger cars in concern with principal aspects and recent trends are presented.
\end{abstract}

Keywords - Resistance spot welding, Unconformities, Properties of Aluminium, Preparation of specimen, Types of electrode tips, Applications of RSW electrodes, Minimization of deterioration of electrode tip.

\section{INTRODUCTION}

Welding is the process of joining two metals permanently through the application of suitable combination of temperature, pressure and metallurgical conditions locally. Fabrication and repair works of metal products in every industry, welding is the principal means. Welding is extensively used in automotive industries in major areas of applications. RSW is most commonly used welding methods for automotive applications. The new technologies in welding area as made possible the noticeable reduction in weight of the vehicle and increase in fuel economy and efficiency. The light weight automobile design and construction have significantly increased and in the last decades specific solutions have been developed based on the intensive use of Aluminium as modified or new alloys.

The requirements and demands of customers regarding safety and luxury along with fuel economy resulted in reinforcement of light materials along with thicker sheets and components in major parts of automotive body like frame and chassis. This made the replacement of some parts of body by light materials (like Aluminium alloys) whose mechanical properties are similar or sometimes even better than steel.

\section{RESISTANCE SPOT WELDING}

For many years, RSW is the principle joining method used in automotive industries. On an average a typical body of a car contains 4500 spot weld joints [1]. The joint in RSW method is made by the generation of heat due to the resistance offered by the work pieces for current flow and simultaneously applying the force (pressure). The electrodes are made of Copper and they conduct the weld current where the weld is to be made and they also serve to apply force on to the weld spot area to form a strong joint. The heat for joining the parts in resistance spot welding is an effect of the heat generated because of electrical resistance of welding circuits according to Joule-Lenz Law (See Fig.1):

$$
Q(t)=\int_{0}^{\tau} I(t) \cdot R \cdot d t
$$

Where: 
Q - generated heat,

I - welding Current,

$\mathrm{R}$ - electrical resistance of welding circuit,

$\mathrm{t}$ - welding time.
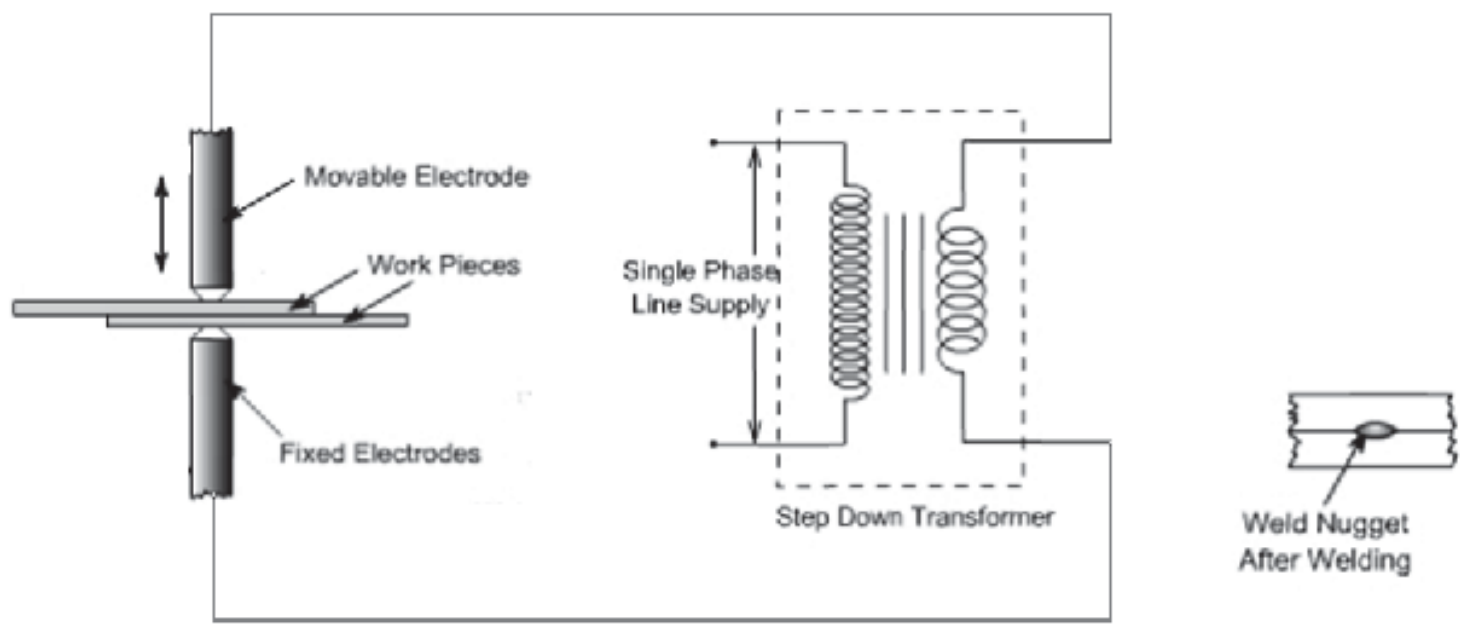

Fig.1. Schematic view of principle of spot welding process

To form a car body in automotive industries the sheet metals are welded by using RSW process which is automated in the form of robotic spot welding.

As resistance spot welding is automated, care should be taken for obtaining the solid weld (nugget formation) without any defects [2]. If defects are introduced into the nuggets then the bond will be weak and there may be a possibility of joint failure which may lead into total destruction of the joint. The most common defects/unconformities of spot weld joints are (See Fig.2):

$>$ Bad shape of welding nugget.

$>$ Cracks inside/around welding nugget.

$>$ Small diameter nugget.

$>$ Deep indentation of welding electrodes on sheets.

$>$ Cold weld.
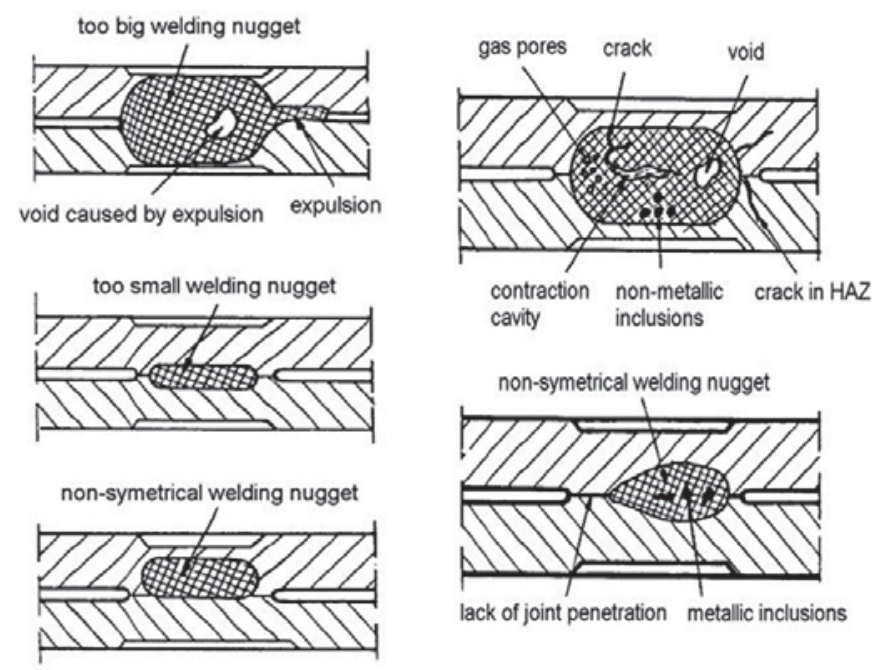

Fig.2. Common unconformities in RSW 


\section{PROPERTIES OF ALUMINIUM}

Aluminium and its alloys are silvery white in color and have density from $2.6 \mathrm{~g} / \mathrm{cm}^{3}$ to $3.0 \mathrm{~g} / \mathrm{cm}^{3}$. It is highly reflective to heat radiation as well as light. It has got high conductivity towards thermal and electricity. One very impressive characteristic of Aluminium is that during heating it does not change its color.

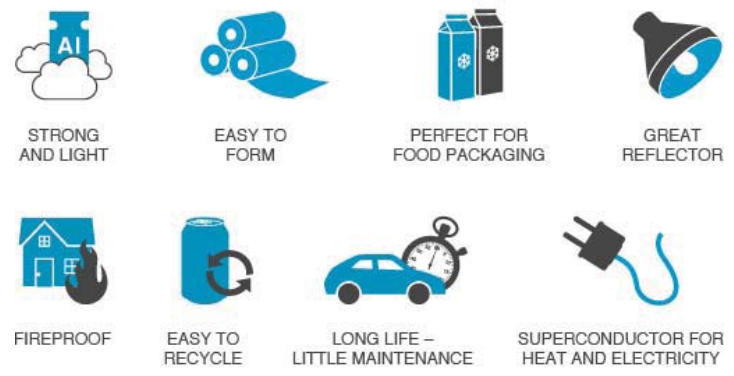

Fig.3. Dramatic view of Aluminium properties

Pure Aluminium melts at $660^{\circ} \mathrm{C}$, whereas, depending upon the composition of alloying components, melting range of Aluminium alloys is from $480^{\circ} \mathrm{C}$ to $660^{\circ} \mathrm{C}$. Comparative physical properties of Aluminium alloys and mild steel are presented in table 1 .

Table 1 Physical properties of Aluminium alloys and mild steel. [3]

\begin{tabular}{|l|l|l|l|l|l|}
\hline & $\begin{array}{l}\text { Thermal } \\
\text { conductivity } \\
(\mathrm{W} / \mathrm{cm} . \mathrm{K})\end{array}$ & $\begin{array}{l}\text { Melting } \\
\text { Temp. }\left({ }^{0} \mathrm{C}\right)\end{array}$ & $\begin{array}{l}\text { Electrical } \\
\text { Conductivity } 10^{6} \\
(\mathrm{~S} / \mathrm{M})\end{array}$ & $\begin{array}{l}\text { Density } \\
\left(\mathrm{g} / \mathrm{cm}^{3}\right)\end{array}$ & $\begin{array}{l}\text { Coef. Of } \\
\text { thermal } \\
\text { expansion, }\end{array}$ \\
\hline $\begin{array}{l}\text { Aluminium } \\
\text { alloys }\end{array}$ & $1.2-2.37$ & $480-660$ & $14.3-37.7$ & $1.7-3.0$ & $22-23$ \\
\hline Mild Steel & $0.32-0.66$ & 1560 & $5-10$ & 7.8 & 11.4 \\
\hline
\end{tabular}

Aluminium is fully recyclable. The scrap of Aluminium can be recovered easily. Without changing the quality, it can be recycled again and again and yet it retains its properties as it is obtained from its ore. The physical properties of Aluminium Alloy series of 6061 \& 6063 are shown in table 2 [4].

Table 2: Physical properties of Aluminium alloys

\begin{tabular}{|l|l|l|l|}
\hline Al Series & Yield Strength $(\mathrm{MPa})$ & Tensile Strength $(\mathrm{MPa})$ & $\begin{array}{l}\text { Elongation } \\
(\%)\end{array}$ \\
\hline $6061-\mathrm{T} 4$ & 110 & 207 & 16 \\
\hline $6061-\mathrm{T} 6$ & 240 & 290 & 8 \\
\hline LF6061 - T4 & $105-130$ & $230-251$ & $7-10$ \\
\hline LF6061 - T6 & $220-234$ & $310-337$ & $4-6$ \\
\hline $6063-\mathrm{T} 4$ & 62 & 131 & 14 \\
\hline $6063-\mathrm{T} 6$ & 172 & 207 & 10 \\
\hline LF6063-T4 & $71-93$ & $127-148$ & $8-11$ \\
\hline LF6063 - T6 & $161-181$ & $210-236$ & $5.5-7$ \\
\hline
\end{tabular}

\section{RESISTANCE SPOT WELDING OF ALUMINIUM}

The spot welding process involves 3 main parameters that should be controlled. They are:

i. Weld current

ii. Weld time

iii. Weld force.

Depending on the material, its properties and its thickness the above said process parameters has to be maintained for obtaining a solid spot weld joint with significant nugget formation and with very good strength. 
As Aluminium is a good conductor of heat, considerable heat dissipation takes place while welding [5]. To overcome this temperature required for melting of Aluminium alloys $\left(400^{\circ} \mathrm{C}\right.$ to $\left.660^{\circ} \mathrm{C}\right)$ should be achieved very fast (with in fraction of second). This is possible only when very high current is passed through the electrodes within few cycles of time [6]. This is the reason that for making a RSW joint to happen in Aluminium alloys, very high weld current with low weld time and optimized weld force are used.

A typical example of comparison of RSW parameters between joining of steel plates of $1.0 \mathrm{~mm}$ thickness and Aluminium plates of $1.0 \mathrm{~mm}$ thickness is given in the Table 3 .

Table 3 - RSW parameters for 1.0 + 1.0 mild steel and Aluminium sheets [7]

\begin{tabular}{|l|l|l|}
\hline Material & Mild Steel & Aluminium alloys 5 \& 6 series \\
\hline Weld current $(\mathrm{kA})$ & 11 & 25 \\
\hline Weld time (cycle for $50 \mathrm{~Hz})$ & 8 & 4 \\
\hline Weld force $(\mathrm{kN})$ & 2.7 & 2.5 \\
\hline
\end{tabular}

\section{ELECTRODES FOR RESISTANCE SPOT WELDING OF ALUMINIUM}

One of the key elements in RSW process is electrode. The material of a typical RSW electrode must have high thermal conductivity, electrical conductivity and high hardness. Because of the conducting properties of Copper material, the electrodes for RSW are made from Copper or Copper alloy material. Different shapes of tool tips used for RSW are shown in Fig.4.

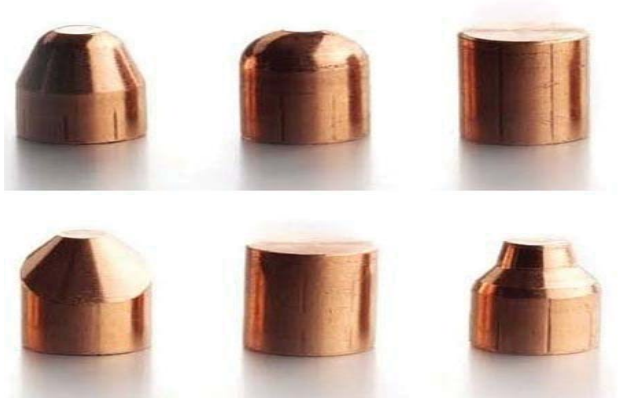

Fig.4. Different shapes of electrode tips.

The main problem concerned with RSW electrodes with Aluminium and its alloys is the relatively low lifetime of the electrodes [8]. This can be a noticeable problem in mass production of RSW of Aluminium material. A typical pure electrolytic Copper has 100\% IACS (International Annealed Copper Standard), which is a unit of electrical conductivity for metals and alloys relative to a standard annealed copper conductor; an IACS value of $100 \%$ refers to a conductivity of $5.80 \times 10^{7}$ siemens per meter $(58.0 \mathrm{MS} / \mathrm{m})$ at $20^{\circ} \mathrm{C}$, but it has relatively low hardness and has very high tendency to alloying with Aluminium. And thus because of high pressure, high temperature and alloying process during RSW, the rapid deterioration of tips surface takes places which involves electrode alloying with Aluminium, pickup effects, cavitations and pitting effects, and because of this the weld quality decreases significantly [9].

The pure Copper is alloyed with Cadmium, Zirconium, and Chromium for achieving higher hardness of electrode. It is also dispersion strengthened with $\mathrm{Al}_{2} \mathrm{O}_{3}$ (Aluminium Oxide) for obtaining good hardness, which increases tip life.

For the spot welding of Aluminium resistance welders manufacturing association has recommended to use group a class 1 Copper alloys. Because of high electrical conductivity, group A class1 alloys can be used for pure Aluminium worksheets where as groupA class 2/1 and group A class 2/2 can be used for Al-Mg and Al-Mg-Si alloys because of their high hardness [3]. The electrode materials and its properties are presented in Table 4. 
Table 4: Properties and Applications of RSW electrodes [3]

\begin{tabular}{|l|l|l|}
\hline Cu Alloy class & A1 & A2/1 \& A2/2 \\
\hline Properties & Conductivity: 95\% - 100\% IACS & $\begin{array}{l}\text { Conductivity: 80\% IACS } \\
\text { Hardness: } 130-170 \mathrm{HV}\end{array}$ \\
\hline Application & $\begin{array}{l}\text { Resistance welding of Al \& its } \\
\text { alloys }\end{array}$ & $\begin{array}{l}\text { Resistance welding of wild } \\
\text { steel, brass, A1 alloys }\end{array}$ \\
\hline
\end{tabular}

Physical and chemical properties of Copper alloys used for electrodes RSW of process in automotive industries are given in Table 5

Table 5: Composition, Physical, Mechanical Properties of Copper alloys as electrodes [10]

\begin{tabular}{|l|l|l|l|l|}
\hline Alloy & Composition & Hardness (HB) & Conductivity (\% IACS) & $\begin{array}{l}\text { Tensile strength } \\
\text { (MPa) }\end{array}$ \\
\hline CRM16 X & $\begin{array}{l}\text { Cr: }>0.40 \% \\
\text { Zr: } 0.3-0.15\end{array}$ & 160 & $76-46$ & 480 \\
\hline BICOP & Al: $0.60 \%$ & 150 & 85 & 430 \\
\hline CB 4 & $\begin{array}{l}\text { Co: } 2.2 \% \\
\text { Be: } 0.5 \%\end{array}$ & $240-260$ & $>43$ & 700 \\
\hline
\end{tabular}

\section{PREPARATION OF SURFACE OF MATERIAL}

Aluminium is highly oxidize prone material. It easily reacts with $\mathrm{O}_{2}$ in atmosphere and forms oxides on its surface. If oxides are present then the current conduction will be decreased. So it becomes essential that the surface of material that is to be spot welded has to be prepared so that the oxides are removed from the surface and the current is conducted through the plates. As the aluminium material highly conducts heat, it is very much necessary that very high amperage current is passed through the electrodes for very low cycles of time pulses, so that heat dissipation will not effect and the melting of aluminium is achieved and proper nugget is formed thoroughly [11].

For preparing aluminium surface first the material is to be cleaned thoroughly with a cloth and then an emery paper of 200 grade or 180 grade should be used for mechanical cleaning of the surface (both sides). Then the material should be dipped in a solution of water added with pallets of sodium hydroxide (2-3 for $100 \mathrm{ml}$ of water) and left for around 5-10 seconds until bubbles are formed on the surface which shows the deoxidizing taking place [12]. Then the surface of material should be neutralized by washing it off with clean distilled water. Then the surface should be thoroughly wiped using a neat cloth. Now the spot welding should be done immediately so that the oxides are not formed on the surface because of time gap [13]. Thus the proper nugget size can be achieved for aluminium material.

\section{SUMMARY AND CONCLUSION}

For many automotive applications such as structural components, chasis and autobody, aluminium is the material of choice due to its good formability, corrosion resistance and low weight [14]. The use of new improved alternative materials necessitated most efficient welding techniques.

Resistance spot welding is the most popular method of joining body sheets.

The physical properties of aluminium alloys are discussed and compared with mild steel. The principle of resistance spot welding is explained.

The electrodes that are used in resistance spot welding of aluminium alloys should be selected such that it has high thermal and electrical conductivity. So Copper material can be used as electrode. For achieving higher hardness of electrode pure Copper is alloyed with cadmium, Zirconium, Chromium, so that the tips deterioration can be minimized.

The process parameters that should be controlled for obtaining a strong bond of aluminium material are elaborated. 
For obtaining a solid nugget, the surface of aluminium alloy material should be thoroughly prepared for the removal of oxides from the surface to serve the purpose of passage of very high current through relatively very low cycles of time.

\section{ACKNOWLEDGEMENT}

The authors would like to thank the Principal and the Head of the Department of Mechanical Engineering of Institute of Aeronautical Engineering for their encouragement, support and granting permission to publish this work. The authors also express their sincere thanks to authorities of JNTU Hyderabad for their support and permission to present this research work.

\section{REFERENCES}

[1] Devarasiddappa. D, "Automotive Applications of Welding Technology - a study” International Journal of Modern Engineering Research, Vol. 4 | Iss.9| Sept. 2014 | 13|

[2] H.P.Falkenstein, W.Gruhl, G.Scharf; Metallwissenschaft und Technik 37/12 (1983) p.1197, H.P. Falkenstein, VDI-Berichte 65 (1984) VDIVerlag Düsseldorf

[3] Welding Handbook, Vol. 3, 8th Edition, American Welding Society, 1992.

[4] KGP study, aluminium average content for new European Cars in 2005.

[5] C. Lahaye, J. Hirsch, D. Bassan, B. Criqui, P. Urban, M. Goede, in "Aluminium Alloys, Their Physical and Mechanical Properties" edited by J. Hirsch et.al. proceedings ICAA- 11 (2008) Aachen ISBN-10: 3-527-32367-8 p. 2363-237

[6] Aloca Inc.: Spinella D.J., Brockenbrough J.R., Fridy J.M.: Trends in aluminium resistance spot welding for the auto industry, Vol. 84, No. 1, 2005, pp. 34-40.

[7] A. AMBROZIAK, M. KORZENIOWSKI : Using resistance spot welding for joining aluminium elements in automotive industry, ARCHIVES OF CIVIL AND MECHANICAL ENGINEERING, Vol. X, 2010, pp. 10.

[8] Li Z., Hao C., Zhang J., Zhang H.: Effects of sheet surface conditions on electrode life in resistance welding aluminium, Supplement to Welding Journal, Vol. 86, No. 4, 2007, pp. 81-89.

[9] Rashid M., Fukumoto S., Medley J.B., Villafuerte J., Zhou Y.: Influence of lubricants on electrode life in resistance spot welding of aluminium alloys, Welding Journal, Vol. 86, No. 3, 2007, pp. 62-70.

[10] Electral, Le bronze Industrial datasheets.

[11] Jürgen Hirsch, Eike Brünger, Stefan Keller, Karl Kipry, in "Aluminium Alloys, Their Physical and Mechanical Properties" edited by J. Hirsch et.al. proceedings ICAA- 11 (2008) Aachen ISBN-10: 3-527-32367-8 p. 2388-2393

[12] E.Gold, W.Horn, J.Maier; Metall 42/3 (1988) p 248

[13] Aluminium Automotive Manual" Internet address www.eaa.net/aam

[14] Zhou Y., Fukumoto S., Peng J., Ji C.T., Brown L.: Experimental simulation of surface pitting of degraded electrodes in resistance spot welding of aluminium alloys, Materials Science and Technology, Vol. 20, No. 10, 2004, pp. 1226-1232. 